\title{
토양환경분야 연구동향 및 전망
}

\author{
양재의 · 옥용식 · 정덕영 ${ }^{*}$ \\ 강원대학교 바이오자원환경학과, ${ }^{1}$ 충남대학교 생물환경화학과
}

\section{Future Directions and Perspectives on Soil Environmental Researches}

\author{
Jae E. Yang, Yong-Sik Ok, and Doug-Young Chung ${ }^{1 *}$ \\ Dept. of Biological Environment, Kangwon National University, Chunchon 200-701, Korea \\ ${ }^{1}$ Dept. of Bio-Environmental Chemistry, Chungnam National University, Daejeon 305-764, Korea
}

\begin{abstract}
This paper reviews the future directions and perspectives on the soil environmental researches in the 21 century. Previously, the principal emphasis of soil environmental researches had put on the enhancement of food and fiber productions. Beside the basic function of soil, however, the societal needs on soil resources in the 21 st century have demands for several environmental and social challenges, occuring regionally or globally. Typical global issues with which soil science should deal include food security with increasing agronomic production to meet the exploding wordd population growth, adaptation and mitigation of climate change, increase of the carbon sequestration, supply of the biomass and bioenergy, securing the water resource and quality, protection of environmental pollution, enhancing the biodiversity and ecosystem health, and developing the sustainable farming/cropping system that improve the use efficiency of water and agricultural resources. These challenges can be solved through the sustainable crop production intensification (SCPI) or plant welfare concept in which soil plays a key role in solving the abovementioned global issues. Through implementation of either concept, soil science can fulfill the goal of the modem agriculture which is the sustainable production of crops while maintaining or enhancing the ecosystem function, quality and health. Therefore, directions of the future soil environmental researches should lie on valuing soil as an ecosystem services, translating research across both temporal and spatial scales, sharing and using data already available for other purposes, incorporating existing and new technologies from other disciplines, collaborating across discipline, and translating soil research into information for stakeholders and end users. Through the outcomes of these approaches, soil can enhance the productivity from the same confined land, increase profitability, conserve natural resource, reduce the negative impact on environment, enhance human nutrition and health, and enhance natural capital and the flow of ecosystem services. Soil is the central dogma, final frontier and new engine for the era of sustainability development in the $21^{\text {st }}$ century and thus soil environmental researches should be carried according to this main theme.
\end{abstract}

Key words: Soil environmental research, Global issues, Climate change, Multidisciplinary, Sustainability

\begin{abstract}
서 언
약 만여년 전 농경시대가 도래한 이후에 토양은 인간의 정주공간을 제공하고, 식물의 물리적 지지기반을 제공함과 동시에 식물에게 필요한 필수 영양소를 제공하는 기본적 기 능을 보여주고 있다. 만약 2 3백 년 전에도 지금과 같이 IT 를 기반으로 한 학술정보가 존재한다면 그 당시의 토양 연 구의 중심은 식량생산 증대, 섬유질 (fiber) 생산, 그리고 거
\end{abstract}

\footnotetext{
접수 : 2011. 10. 16 수리 : 2011. 12. 1

*연락저자 : Phone: +82428216739

E-mail: dychung@cnu.ac.kr
}

주에 필요한 물질 생산에 초점을 맞추고 있다고 판단된다. 아울러 산업혁명 이후의 토양연구도 마찬가지 경향이었을 것이다. 이후 20 세기까지 토양학자들은 토양관리 기술과 집 약적 생산기술 개발을 통하여 녹색혁명을 성취하는데 크게 기여하였다. 집약적 생산 기술은 식량생산의 획기적 증대를 통하여 인류의 기아, 영양실조 및 가난으로부터 어느 정도 해방시켰을 뿐 아니라 일부 식량안보를 확보하는데 기여하 였다.

토양관리기술을 통한 집약적 생산은 토양의 순기능을 보 여준 반면 다양한 영역에서 역기능을 보여주었다. 대표적인 예를 들면, 농업분야 자원의 고갈, 토양의 질 저하, 온실가 스 배출 및 기후변화에의 기여, 농경지 확보의 어려움에 따 
른 미래 생산성 위협, 수자원 고갈, 수질과 토양을 포함하는 환경오염 등이다. 21 세기에는 산업의 발전과 경제성장이 고 도화 되면서 현대농업의 패러다임이 변화되고 있다. 현대 농업은 식량의 확보 뿐 아니라 식품의 기능성과 안전성, 인 간 건강, 환경과 생태계의 건전성을 고려해야 한다. 그래서 각 국에서는 친환경농업, 저투입지속적 농업, 유기농업 등 의 형태를 강조하고 있는 실정이다. 따라서 토양환경의 연 구는 전통적인 연구 뿐 아니라 이와 같은 소비자의 사회적, 기능적 요구를 수용하는 방향으로 전환되어야 할 것이다.

21세기의 미래 토양환경연구는 토양의 기본적인 기능은 물론이고, 사회의 요구를 수용하는 복합적인 연구로 전환해 야 한다. 아울러 토양 연구는 토양학 분야 밖에서 급속도로 개발되고 있는 BT, IT, NT, ET 분야 등의 유망 신기술을 아 웃소싱 (outsourcing)해야 하는 명제를 안고 있다.

본 논문에서는 변화되고 있는 농업의 사회적 요구와 국 내외 연구동향을 바탕으로 현대농업에서 요구되는 목표를 달성하기 위해 토양환경의 연구가 지향하는 방향을 고찰하 고자 한다.

21세기 토양환경 연구의 사회적 요구 토양에 관한 소비자의 요구는 농업의 목표나 지역, 경제, 토지이용 등에 따라 다양할 수밖에 없다. 선진국에서 최근 수행되고 있는 토양환경 연구의 기본 방향과 영역을 살펴보면, 식량, 섬유질, 주거를 위한 물질 생산 이외에 식량자급, 에너지, 기후변화, 생물다양성, 산업소재생산, 수자원, 환경 및 생태계 건전성, 미생물, 의약품 등 생물소재, 자원 확보 등의 영역을 포함하 고 있다 (Fig. 1).

토양환경의 연구는 현대사회에서 요구하는 수요를 충족 시킬 수 있는 방안에 맞춰 진행되어야 한다. 이러한 사회적 수요를 충족시켜 줄 수 있는 농업의 개념을 FAO (2011)에서 는 지속적 작물생산증대 (SCPI: Sustainable Crop Production Intensification)라고 부르고 있다. SCPI는 토양과 사회적 요
구의 조화를 통하여 제한된 경지에서 생산성을 향상시키고, 농가 소득을 극대화하며, 자연자원을 보전하고, 환경에의 부 정적 영향을 최소화하고, 자연생태계의 순환을 향상시키는 목표를 두고 있다.

SCPI와 유사한 개념으로 우리나라에서는 식물복지 (Plant Welfare) 개념이 제시되었다 (Yang, 2008, 2011). 식물복지 의 개념은 SCPI에서 추구하는 목표를 모두 포함할 뿐 아니 라 인체영양과 건강의 개념을 추가적으로 포함하고 있다. 식물복지는 식물이 건강한 토양환경에서 재배되고 균형 잡 힌 영양소를 보유해 이를 이용하는 동물과 인간의 건강 복 지 증진에 기여하자는 개념으로 식물체 자체보다는 이를 이 용하는 개체의 건강과 복지에 더 중요성을 부여하고 있다.

$\mathrm{SCPI}$ 와 식물복지는 현대농업의 목표를 통합적으로 제시 하는 개념이며, 이를 달성하기 위해 토양환경 연구의 중요성 을 강조하고 있다. 아래에서는 SCPI, 식물복지 및 토양환경연 구가 추구해야 할 범위와 내용에 관하여 고찰하고자 한다.

지속적 작물생산증대 (SCPI: Sustainable Crop Production Intensification) FAO (2011)에서는 지속적 작물생산증대를 'Save and Grow'의 개념으로 제시하고 있다. 'Save and Grow' 에서는 해결해야 할 도전 명제에 대하여 6가지 연구방향을 제시하고 있다. 폭발하는 세계 인구를 먹여 살리기 위해서는 작물생산을 극대화하는 길 밖에 없으나 생산자는 예기치 못한 많은 제약에 직면하게 되며, 농업은 작물을 키우기 (grow) 위 해서는 보전 (save)해야 한다는 명제를 제시하고 있다. 이는 작물생산을 극대화하기 위해서는 자원과 환경을 보전해야 할 뿐 아니라 이에 필요한 다양한 전략을 통합적으로 이행 해야 하는 현대농업의 목표를 압축하고 있다.

FAO (2011)에서는 'Save and grow’의 목표를 달성하기 위하여 작물과 품종, 작부체계, 수자원 관리, 토양건강, 식물 보호 및 정책에 관한 추진 방향을 제시하고 있다. 생산자는 다양한 범위의 농업생태계, 작부체계 및 기후변화에 적합한

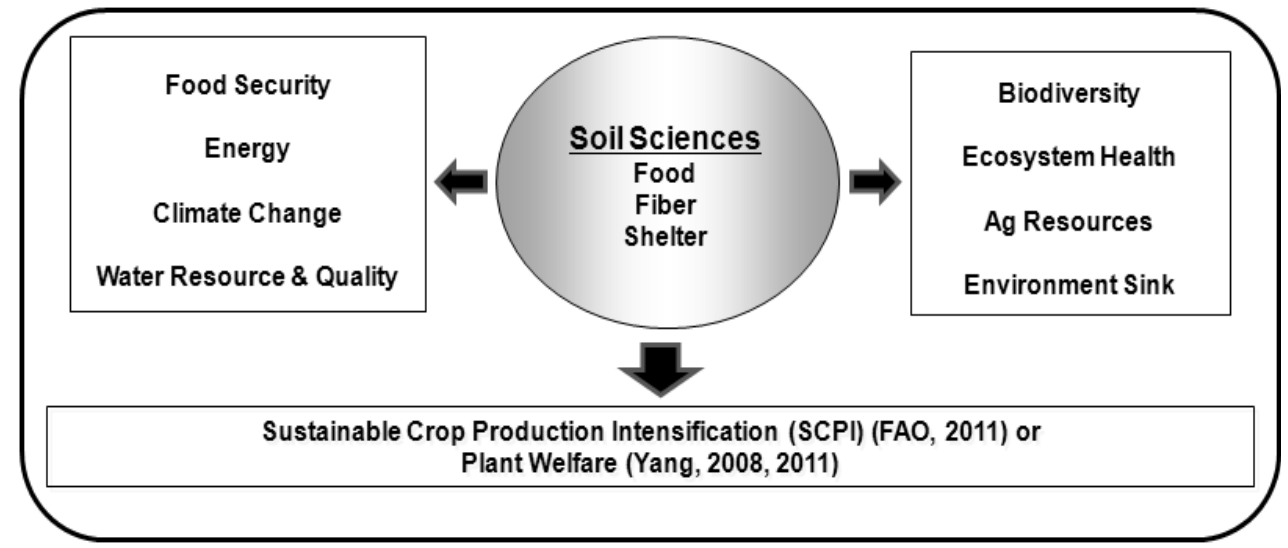

Fig. 1. Basic functions of soil (circle) and the societal needs for soil sciences to cope with the global issues in the 21st century (rectangle). 
작물 품종을 필요로 하며 작물은 유전적으로 다양한 특성을 지닐 수 있도록 개량되어야 한다. 작물생산 극대화는 적절 한 작부체계에 의해 달성되어 생산자와 사회에 생산적, 사 회경제적 및 환경적 이윤을 제공할 수 있어야 한다. 지속적 생산극대화는 관개 및 생산 활동을 위한 정밀한 기술을 필 요로 하는데 이는 수자원을 보전하기 위해 생태학적 접근방 법을 필요로 한다. 농업은 건강한 토양의 중요성을 인식하 고, 식물영양을 위한 자연자원을 확보하고 광물질비료를 현 명하게 사용함으로서 생산성의 극대화를 성취할 수 있는 기 본 방향으로 전환해야 한다. 농약은 병해충을 방제함과 동 시에 천적을 죽일 수 있으므로, 농약의 과다 사용은 생산자, 소비자 및 환경에 악영향을 초래할 수 있다. 식물보호의 기 본은 건강한 농업생태계를 유지하는 방향으로 추진되어야 한다. 소규모의 생산자로 하여금 지속적 작물생산 극대화를 권장하기 위해서 농업 정책의 개발과 기관 역할에 있어서 획기적인 변화가 필요로 한다.

$\mathrm{SCPI}$ 에서 추구하는 목표는 개량된 작물의 품종과 적합한 작부체계를 도입하고, 수자원을 포함한 농업자원을 보전하 며, 토양과 농업생태계의 건전성을 유지하면서 생산성을 극 대화한다는 것이다. 따라서 SCPI의 목표는 농업생산성을 극 대화함에 있어서 기본적인 요소들과 토양자원의 지속적이며 통합적인 활용을 필요로 하고 있다. 토양환경 연구가 복합 적이고 타 분야에서 개발되는 요소기술을 포함하는 연구방 향으로 전환되어야 함을 시사하고 있다.

식물복지 동물복지 개념은 70 년대 후반부터 시작된 것 으로 동물을 사육함에 있어서 동물로 하여금 배고픔, 갈증, 질병, 고통, 스트레스 등으로부터 자유로워야 한다는 것으로 현대에 들어 더욱 강조되고 있다. 식물복지는 식물이 건강한 토양환경에서 재배되고 동시에 다량영양소와 미량영양소가 균형 있게 흡수하여 인간과 동물에게 필요한 영양소를 적절 하게 공급해야 한다는 개념이다 (Greenwood, 1989; Grusak and DellaPenna, 1999; Yang, 2011). 경지의 제한, 폭발적으 로 증가되는 인구, 농산물 생산성의 정체와 식량위기, 영양 결핍 등을 고려할 때 식량자급률이 낮은 우리나라에서는 식 물복지의 중요성이 증대되고 있다.

세계적으로 곡물 생산지 토양의 반은 미량요소 중 아연이 결핍되어 있다 (Cakmak, 2002; Greenwood, 1989; Grusak and DellaPenna, 1999). 후진국의 경우 수십억명이 미량요 소 결핍이나 불균형으로 인해 성장 둔화, 면역체계 결핍, 빈 혈, 임신부 사망 등의 문제를 초래하고 있다. 식물복지는 인 간 영양 및 건강과 직결되는 것이므로, 토양으로부터 영양소 를 흡수하는 식물에게 균형있고 충분한 영양소를 공급할 수 있는 토양관리 기술이 제공되어야 할 것이다 (Cakmak, 2002). 이는 종합적인 토양관리 기술이며 아울러 국민의 영양수급 과 관련된 분석 평가도 수반되어 현대 농업에서 중요시 하
는 사회적 요구를 충족시킬 수 있어야 할 것이다.

2050년에는 세계인구가 100억에 도달할 것으로 전망되고 있다. 인구증가와 더불어 식량의 부족은 심화될 것으로 예측 된다. 그동안 식량부족을 해결하기 위해 양질의 토양에서 고 투입 농업기술을 개발하여 생산성을 증대시켜 왔다. 그러나 토양환경이 열악한 조건에서 대부분의 생산자들은 이런 목 표를 달성하기 어려운 실정이다. 생산에 불리한 토양조건에 서 생산성을 높일 수 있는 기술이 필요하다. 토양의 질을 보 전하고, 유실을 방지하며, 환경오염을 줄이고, 농자재의 투 입을 최소화하고, 영양소의 순환을 극대화하며, 수자원을 보 전할 수 있는 지속적 토양관리 기술의 개발이 필요하다. 이를 위해 다양한 모델의 개발과 토양환경에서의 사회적 요구를 충족할 수 있는 기능을 장기적으로 평가할 수 있는 모니터 링 기법의 개발도 필요한 실정이다. BT, IT 등의 유망기술 을 도입해야 할 것이다. 이를 통해 지속적 생산성의 증대와 환경의 보전을 위한 현대 농업의 목표를 달성할 수 있을 것 이다. 이렇게 생산된 농작물은 생산자의 소득증대는 물론이 고 생태계를 보전하며 인간 건강에도 기여할 것이다.

식물복지의 목표를 달성하기 위해서는 인간의 영양과 건 강 증진 이외에도, Figure 1에서 제시한 바와 같이 식량위기 극복, 자원보전, 기후변화대응, 생태계 건전성 유지, 에너지 공급 등의 사회적 요구를 충족시켜야 할 것이다. 이를 위해 서는 학제간 통합적인 기술을 적용해야 할 것이며 환경에서 일어나는 생물지구화학적 토양반응을 활용하고, 토양자원을 지속적으로 관리해야 하며, 수자원과 에너지의 균형을 유지 할 수 있어야 할 것이다. 토양은 식량확보와 환경 이슈에 관련 된 문제를 해결할 수 있는 통합적 도구라고 표현되고 있다 (Lal, 2009).

식물복지는 건강하고 영양소가 균형있게 흡수된 작물의 지속적 생산이라 칭할 수 있다. 따라서 식물영양은 토양학과 더불어 식물복지를 달성하는데 크게 기여할 수 있다. 식물유 전학 및 분자생물학 등 다양한 학문과의 학제간 연구를 통 해 해결될 수 있으며, 토양 환경에서 일어나는 자연적 생물 지구화학적 과정을 이해해야 하며, 토양자원의 지속적 관리 기술이 접목되어야 한다 (Yang, 2011).

토양환경연구의 영역확대 식량과 환경에 관련된 범 지구적 심각성을 고려할 때 사회적으로 요구되는 토양의 기 능은 다각적인 측면에서 바라보아야 한다. Lal (2008)에 의 하면 토양은 기후변화 영향을 경감하기 위한 탄소 격리, 오 염원의 완충과 안전한 수용, 도시 산업폐기물의 수용체, 인 류역사의 보관처, 생물자원과 다양성의 보전, 물과 이온의 순 환 유지와 강화, 자연재해와 인위적 재해가 환경에 미치는 영향의 완화, 경관과 생태계의 가치를 유지함과 동시에 문 화적 가치를 보전하는 기능을 보여주어야 한다고 설명하고 있다. 토양은 유한한 자원이고, 재생되기 어려우며, 부적절한 
관리와 이용 및 기후변화 등으로 인해 질적 저하가 우려되기 때문에 토양자원의 지속적 관리의 중요성은 21 세기에 들어 더욱 강조되고 있는 실정이다. 따라서 토양환경의 연구 영 역이 크게 확장되어야 할 것이다.

19 세기와 20세기 중반까지의 토양연구의 중심은 증가되는 인구에게 충분한 식량을 공급하기 위한 생산성 증대에 맞춰 져 왔다 (Lal, 2008). 21세기에 접어들면서 인구의 폭발적인 증가와 고도의 산업 경제발전과 더불어 토양연구에 관한 사 회적 요구는 다양하게 변화되고 있다. 현대 사회에서 토양학 에 요구하는 전망은 식량 공급 이외에 기후변화 대응, 에너 지공급, 수자원 확보, 도시화를 위한 토지의 확보와 생산을 위한 토지의 확보, 농촌의 소득 증대 및 생활 향상, 도시 산업 폐기물의 처리를 위한 토양의 확보, 토양과 수질오염 방지, 종다양성 확보와 생태계 건전성 유지 등에 초점을 맞추고 있다 (Lal, 2009). 이러한 사회적 이슈와 요구에 대한 해결책 으로 토양환경의 연구는 첨단 과학기술을 통합적으로 도입 하여 토양자원을 지속적으로 관리하는데 있다. 21 세기에 필요 로 하는 토양환경연구의 영역을 간략하게 소개하고자 한다.

식량확보 UNFPA 자료 (2011)에 의하면 2011년을 기점 으로 세계 인구는 70 억을 돌파했으며 2050년에는 100 억에 도달할 것으로 예측되고 있다. 이중 약 35 억 명의 인구 증가 가 아시아와 아프리카의 개발도상국에 일어날 것으로 예측 되고 있다 (Cohen, 2003). 경제발전과 더불어 이 지역의 식 생활 경향이 식물성에서 동물성으로 빠르게 변화되고 있으 며 아울러 이 지역의 토양자원은 자연적 또는 인위적 훼손에 민감하며 기후변화와 개발 등에 의해 토양자원의 질적 저하 가 매우 심각한 지역이다 (Lal, 2008). 이들에게 필요한 식 량을 제공하기 위해서는 토양에서의 면적, 시간, 투입 당 생 산성을 향상시켜야 한다. 유한한 토양자원에서 이러한 식량 을 확보하기 위해서는 혁신적인 토양관리 기술의 개발 및 이행이 필수적으로 요구된다.

개발 가능한 토양관리 기술은 작물에게 공급되는 영양소 (비료)와 물의 이용효율을 극대화하고 동시에 이들의 손실 을 최소화할 수 있어야 한다. 질이 저하된 토양의 경우는 유 기물의 증가, 필수영양소의 수지 (balance) 증대, 토양유실 의 효율적 저감, 토양구조 및 경운성 개선, 토양생물의 활성 및 다양성 증대, 물질순환을 증대시키고 투입자원의 이용효 율을 증대시키는 작부체계 구축 등의 기술을 통하여 개량되 어야 한다. 이러한 복합적이고 혁신적인 토양관리 기술은 현대에 발전되고 있는 BR, IT 등의 유망 기술을 도입해야 하며 아울러 지역특이적인 관리방안과 새로운 농자재의 개 발이 필요한 실정이다.

전 세계 경작지의 $80 \%$ 이상이 천연강우에 의존하거나 비 관개 방식에 의존하여 작물을 생산하고 있다 (Lal, 2008). 우리나라는 강수량이 많으나 여름철에 집중되어 있고 수자
원을 효율적으로 이용, 보전하는 방안이 필요한 실정이다. 수자원의 활용도 중에서 작물생산을 위해 사용되는 농업용 수의 의존도가 매우 높으므로 (Yang et al., 2008), 토양에서 의 물이용과 절약 기술도 식량 확보를 위한 중요한 연구과 제이다.

탄소격리 (Carbon Sequestration) 산업의 발전과 자연 계에서 다양한 형태의 온실가스가 배출되어 기후변화를 초 래하고 있다. 세계적으로 온실가스의 저감과 작물의 기후변 화 적응 및 대응 방안에 관하여 많은 연구를 수행하고 있다. 국가적이나 농업적으로 볼 때 현대는 탄소의 시대라고 불릴 정도로 녹색성장을 화두로 삼고 있다.

농업적으로 볼 때 육상생태계에서의 탄소격리와 토양의 질 향상을 통해 토양이 온실가스의 배출원 대신 저장고 역 할을 할 수 있는 관리 기술의 개발이 매우 중요하다. 이는 토 양학자 뿐 아니라 작물학자, 생태학자, 농학자 등에게도 해 당된다. 생태계가 탄소를 저장하고 순환하는데 영향을 미치 는 과정의 이해도 중요하지만 토양학자는 토양에서의 격리 하는 탄소를 통해 탄소배출권을 거래하는 방법론을 개발할 필요가 있다. 토양에서 메탄과 아산화질소를 저장하고 이를 이산화탄소 당량으로 전환한 후 이를 거래할 수 있는 도구 의 개발도 필요하다. 토양유실 방지, 비료관리, 작부체계의 개선, 관개 기술의 개선 등을 통해 토양의 질이 개선되면 온 실가스의 방출이 저감되고 이를 통한 탄소배출권을 거래할 수 있다면 이는 생산자에게 소득에 도움이 될 수 있거나 또 는 토양관리 개선에 관한 인센티브가 될 수 있다.

탄소격리는 토양의 질 회복과 식량생산과 밀접하게 관련 되어 있다. 토양의 질을 향상시키는 과정은 시간이 오래 걸 리나 토양탄소의 저장 증대에 의해 향상될 수 있다. 토양탄 소의 증대는 기후변화에 적응하거나 영향을 감소시키는데 중요하다. 아울러 토양생물의 활성과 다양성을 향상시켜 토 양에서의 물질 순환과 생물지구화학적 반응을 원활하게 진 행되게 해 줄 수 있다. 토양사막화의 방지는 토양과 생태계 의 복원을 촉진하며 이는 탄소의 저장과 관련되어 있다. 이 러한 일련의 과정은 식량생산성과 탄소배출권 향상을 통해 식량확보의 증대를 가져올 수 있다. 탄소격리는 또한 수질 향상, 미세기상, 온실가스 배출 특성과 밀접하게 관련되어 있 다. 따라서 토양에서의 탄소격리를 향상시킬 수 있는 관리 기술 개발과 이의 이행 방안 확립은 토양학자가 수행해야 할 중요한 과제이다.

토양탄소격리는 토양에서 일어나는 단순한 과정이 아니 라 토양환경에서 대기, 수계, 생물계와 복합적으로 반응하여 나타나는 반응이므로 이에 관한 기술을 개발하기 위해서는 관련된 분야의 학자들과의 학제간 공동노력이 필요하다. 21 세기가 직면하고 있는 지구온난화, 기후변화, 탄소격리, 수자 원 보호, 폐기물 처리, 오염지 복원 등의 문제들은 토양에서 
고에너지 소모성 관리방안이나 토양에서 일어나는 생물지구 화학적 반응들을 일부 변경하거나 인위적으로 최적화시켜 해결할 수 없다 (DeJong et al., 2011).

작물은 대기로부터 이산화탄소를 동화하여 유기물로 전환 시키게 되고 유기물의 형태로 탄소를 토양에 저장하게 된다. 또한 식물뿌리, 세균, 곰팡이 들은 이산화탄소와 유기산을 배 출하고, 배출된 유기산은 이산화탄소, 중탄산, 탄산이온으 로 산화되게 된다. 토양용액에 충분한 양의 칼슘이 존재하 게 되면 탄산이온 종은 방해석 (calcium carbonate)의 형태 로 침전되어 탄소를 격리하게 된다. 이 과정에서 볼 수 있듯 이 탄소의 격리는 복잡하고 다양한 반응이 관련되어 있으므 로 토양탄소의 격리 기술의 개발은 복합적인 노력이 필요한 실정이다.

수자원 작물의 생산성은 토양의 비옥도와 비료를 통한 영양소의 공급 뿐 아니라 동시에 수자원의 공급가능성에 크 게 의존하게 된다. 기후 변화에 따라 가뭄을 겪는 경우는 수 자원의 이용에 크게 제한을 받을 수 있다. 수자원 중 농업용 수가 차지하는 비율이 가장 크며, 도시화 및 산업의 발달에 따라 도시생활 용수 및 산업용수의 수요가 급증하게 되므로 농 업용수는 이들과 경쟁적으로 이용되어야 한다 (Moldan, 2007). 우리나라의 경우 농업용수를 $10 \%$ 정도 절약할 경우 이는 도시 생활용수와 산업용수 요구량의 $50 \%$ 정도에 해당될 수 있다 (Yang et al., 2008).

양질의 농업용수의 확보는 수질오염에 의해 위협받을 수 있으며 식생활 패턴이 식물성에서 동물성으로 전환되면서 더 악화될 수 있다 (Clay, 2004; Tillman et al., 2006). 이런 관 점에서 볼 때 토양에서의 관개기술과 물 이용효율을 증대시 킬 수 있는 토양의 관리가 매우 중요하다. BT 분야에서 개 발된 작물의 품종 개선과 IT 분야에서 개발된 센서를 이용 한 자동 관수 장치의 개발 등은 토양학자가 수용하여 복합 관리 기술로 전환해야 할 과제이다. 단위 물 사용 당 최적의 생산량을 추구하고, 관개 과정 중 물의 손실 방지, 토양 수 분 증발 감소를 통한 수자원의 이용효율 증대, 지하부위로 이동하는 수분의 이용 증대, 폐수의 관개수로의 재활용기술 등을 연구해야 할 과제이다. 우리나라에서 주로 사용하는 담수 관개 방법을 점적관수 등의 효율적인 방안으로 전환할 수 있는 기술개발이 필요한 실정이다.

바이오 에너지 현대의 산업시대는 탄소문명 시대로 불릴 정도로 탄소를 함유하고 있는 화석연료와 화합물의 사 용에 크게 의존하고 있다. 화석연료의 사용은 온실가스를 배 출하여 지구의 탄소순환을 방해하고, 기후변화와 지구 온난 화를 초래하고, 강수량과 강우 패턴의 변화를 초래하였다. 탄소의존성을 탈피하는 것은 탄소 중립 또는 비탄소 연료의 개발을 필요로 하며 이 과정에서 토양학자의 역할이 매우
중요하다. 농업생산성을 향상시키기 위해 투입된 비료, 농약, 관개 등의 농자재의 이용효율을 극대화 시킬 수 있어야 한 다. 미래의 연료는 수소와 같은 비탄소 연료에 의존할 수 있 는 방향으로 전환되고 있다.

투입된 농자재의 이용효율 증대는 적절한 토지이용과 합 리적인 작부체계를 통한 바이오매스의 생산에 의해 달성될 수 있다. 이러한 바이오매스 생산을 통해 에탄올과 바이오 디젤과 같은 신재생 바이오에너지가 생산될 수 있고 이는 온실가스의 배출 억제와 대기 중 이산화탄소의 농도를 저감 하는데 중요한 역할을 한다. 옥수수와 같은 작물을 이용하 여 에탄올과 같은 바이오에너지를 생산하는 것은 에너지 생 산에 있어서 비효율적인 과정이며 (Lal, 2008), 식량부족과 위기와 관련되어 논쟁이 많은 부분이다.

작물 잔유물은 에너지 급원으로 간주되고 있다. 1 톤의 lignocellulosic 작물 잔유물은 250-300L의 에탄올에 해당 되며 이는 $16 \times 10^{6} \mathrm{Kcal}$ 열량에 해당될 수 있다. 곡물로부터 유래된 에탄올의 경우 투자대비 에너지 회수율 (EROI; Energy Return on Investment)이 낮다 (Lal, 2005, 2006). 반면에 벼, 밀, 보리, 옥수수 등의 작물잔유물은 토양유실 방지, 수 분보전 및 유기물 함량 증대를 위해 토양 개량제나 멀칭재 료로 활용되어야 하며, 저하된 토양의 질을 개선하는데 활 용되어야 한다. 아울러 작물 잔유물은 폐기물이 아니라 토 양과 수자원의 보전, 영양소의 순환, 비료와 관개수의 이용 효율 증대, 토양생물의 에너지 및 영양소 급원으로 활용되 어 토양생태계의 건전성을 유지하는데 이용되어야 한다. 작 물 잔유물을 수확하는 것은 에너지 소비적 과정이며 토양과 환경에 좋지 않은 영향을 미치게 된다. 따라서 토양학에서 는 작물 잔유물의 이용을 통한 지속적 농업생산성을 향상시 킬 수 있는 관리기술을 개발하여야 한다.

작물을 바이오에너지 생산을 위한 바이오매스로 활용하는 것은 경제적인 측면이나 세계적으로 식량확보를 고려할 때 비 효율적인 것으로 간주된다. 그 대신 바이오 에너지를 생산 할 수 있는 특이성 작물을 재배하는 것이 중요한 접근이다. Lal (2008)은 바이오에너지 연료용으로 이용될 수 있는 식물 을 초본류, 목본류, 호염성식물, 가뭄 저항성 식물 등을 제시 하고 있다. 지구상에서 폭발하는 인구를 위한 식량생산은 2 배 이상 증가 되어야 하나 생산성 증대를 위한 집약적 토지 이용은 매우 제한적이다 (Foley et al., 2005). 따라서 바이오 에너지 생산을 위한 특이 작물의 재배는 한계 농지 또는 여 분의 농경지를 이용해야 할 것이다.

바이오 에너지 생산을 위해서는 우선적으로 바이오매스의 확보가 절대적으로 중요하다. 바이오에너지 생산을 위한 작 물의 개량 (작물학자, BT 학자)과 더불어 이들 작물의 바이 오매스 확보를 위한 재배기술의 개발과 토양관리 기술개발 은 토양학자들의 몫이 될 것이다. 조건불리 지역에서의 바 이오 에너지 작물을 재배하는 것은 토양탄소격리를 증가시 
킬 수 있고 토양의 질과 생태계 서비스를 증대시킬 수 있는 지속적 농업의 일환이 될 수 있다.

바이오에너지 생산을 위한 EROI는 전과정 평가 (LCA: Life Cycle Assessment)를 거쳐 효율성을 가름할 수 있다. 이는 단기적인 이윤 보다는 장기적인 관점에서 자연자원을 지속 적으로 이용되는 관점에서 평가되어야 한다. 단기적인 측면 에서의 바이오에너지 필요성은 식량확보의 심각성과 상충 하게 된다. 바이오에너지 생산을 위해 사용된 작물의 잔유 물이 토양으로 환원되지 않으면 토양의 질 저하를 초래하게 되고 아울러 식량위기를 초래할 수 있다.

환경완충용량 토양은 산업체, 도시 및 가정에서 발생 되는 폐기물의 최종적인 수용체이다. 따라서 토양이 증가되 는 각 종 폐기물을 안전하게 수용할 수 있는지를 평가하는 것은 토양의 질적 측면 뿐 아니라 토양의 환경용량을 평가 함에 있어서 매우 중요한 연구 분야이다. 가축 사육과 음식 물 가공, 가정 및 음식점 등으로부터 다양한 종류의 유기성 폐기물이 발생되고 있으나 생분해성 고형폐기물 (biosolids) 은 에너지 급원이나 토양개량제로서 사용될 수 있다. 이들 의 토양 재활용에 관한 연구가 시급한 실정이다.

토양의 물리화학적, 생물학적 특성은 토양으로 유입되는 폐기물의 분해, 오염물질의 정화, 토양의 질 향상에 매우 중 요한 역할을 한다. 표토에서의 토양의 구조, 토성에 따른 배 수성, 토양미생물의 활성과 종 다양성, 불포화층 (Vadose zone)에서의 불투수층의 존재 유무 등은 토양이 폐기물과 오염물질의 분해, 이동 및 동태를 결정하는 중요한 특성이 되어 토양이 자연적 생물여과 (biomembrane)의 기능을 할 수 있는지를 결정하게 된다.

산업의 발전과 인구 증가에 따라 토양이 폐기물을 처리 하고 수용할 수 있는 환경용량의 중요성도 증대된다. 따라서 토양의 자연적인 생물지구화학적 반응, 물리화학적 특성, 수 리수문학적 특성, 생물 다양성 등은 토양의 환경용량을 증대 시켜 지속적 생산성 뿐 아니라 토양생태계의 건전성을 유지
하는데 크게 기여할 수 있으므로 이에 관한 복합적인 연구 가 추진되어야 할 것이다.

지속적 토양관리와 농업 토양의 전래적인 기능은 작 물생육의 지지 기반을 제공하고 생산성을 높이며 동시에 인 간 정주를 위한 물질의 제공 및 토목적 구조물의 기반을 제 공하는 것이다. 그러나 21 세기에 들면서 인구가 폭발적으로 증가되고, 이에 따른 식량의 확보나 기후변화, 환경오염 등 각종 사회적 이슈가 발생되어 토양의 기능은 식량확보 뿐 아니라 생태계의 건전성을 유지해야 하는 등 영역이 널리 확대되고 있다. 대표적인 생태계의 건정성 유지에 관한 예 를 들면, 토양은 탄소격리를 통해 기후변화 영향을 저감시 키고, 오염물질의 여과 및 변형을 통한 수질 정화, 도시 및 산업폐기물의 수용체, 생물다양성 유지를 위한 각종 유전인 자의 저장고, 인류 문화의 보전 등을 들 수 있다.

현대 농업에서의 토양의 기능은 지속적 토양관리를 통해 극대화될 수 있다. 증가되는 인구에게 공급할 식량의 확보 와 농업생태계의 건전성을 유지하는데 있어서 토양의 역할 이 매우 중요하다. 토지 이용은 지역적인 환경이슈로 간주 되어 왔으나 범지구적 중요성이 증대되고 있다. 토지이용을 경작지, 산림, 수로, 초지 등으로 전환하는 것은 70 억 인구 에게 식량, 섬유질, 물, 정주공간을 제공하는 필요성에 의해 결정될 수 있다. 세계적으로 경작지, 초지, 조림지 및 도시 면적은 지속적으로 증가되고 있으며 아울러 에너지, 수자원 및 비료의 소비량도 동시에 증가되고 있다. 한편 이러한 토 지이용은 생물다양성의 획기적인 감소를 초래하고 있다. 이 러한 토지이용의 변화는 지속적 식량생산, 수자원의 확보, 기후변화 및 대기 질에도 악영향을 미칠 수 있다.

현대 농업에 있어서 토양은 단기적으로 인간의 필요성 (예, 식량)을 충족시키는 것과 장기적으로 물질과 서비스 기 능을 제공하는 생물권의 용량을 유지시키는 것 사이에 조화 를 유지해야 하는 명제를 안고 있다.

Foley et al. (2005)은 토지이용이 상이한, 즉 자연 생태

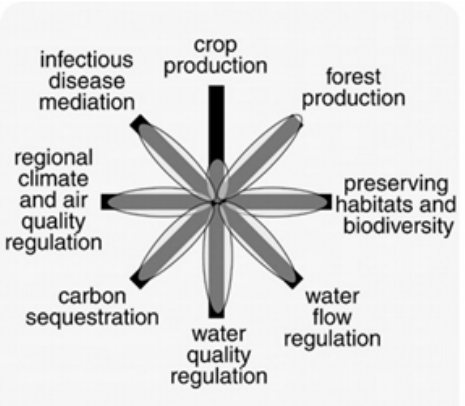

(a)

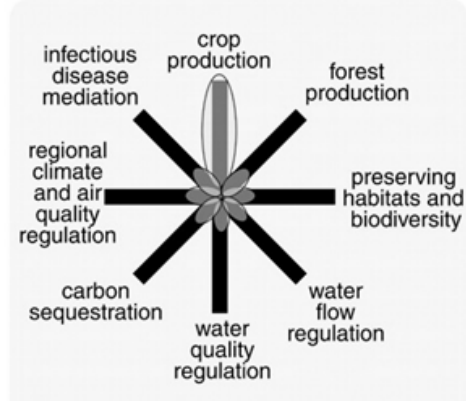

(b)

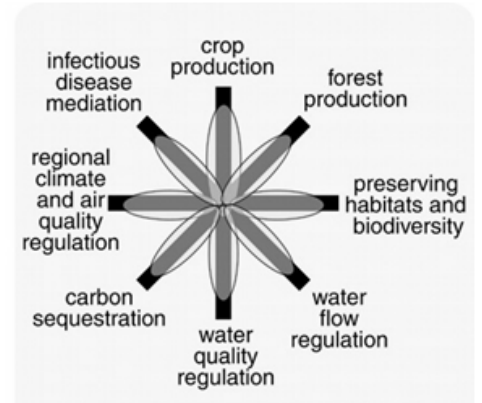

(c)

Fig. 2. The flower diagram of the conceptual framework for comparing land use and trade-offs of ecosystem services for (a) natural ecosystem, (b) intensive cropland, and (c) crop land with restored ecosystem services (Adapted from Foley et al., 2005). 
계, 집약적 작물생산지 및 생태계 기능을 복원한 작물재배 지에서의 생태계의 기능을 비교하여 제시하고 있다(Fig. 2). 자연생태계의 토지이용은 식량생산의 기능이 부족하지만 수 자원 확보, 탄소격리, 종 다양성 보전, 기후 및 대기 질 유지 및 병해충 방제 등의 기능은 우수하다. 그러나 집약적 작물 재배지의 경우는 작물생산성은 우수하나 다른 생태적 기능 과 서비스가 부족하다. 그러나 생태계의 서비스 기능을 복 원한 작물재배지의 경우 작물생산성과 생태계의 기능이 우 수한 것으로 평가하고 있다. 이 그림에서 볼 수 있듯이 생태 계의 기능과 작물생산성의 유지는 토양의 이용과 관리에 따 라 결정됨을 알 수 있다.

토지이용에 따른 부정적인 영향을 완화할 수 있는 전략 은 환경적, 사회적, 경제적 이익을 초래할 수 있는 토양관리 기술에서 찾아볼 수 있다. 단위면적, 비료 사용 단위량 및 단위 물 사용량에 따른 농업생산성을 극대화 할 수 있는 방 안, 토양에서 유기물 함량을 증가시켜 탄소격리, 수분보유 력, 영양소 유효도를 증가시키거나 유지시키는 방안, 도시에 서 녹색공간을 극대화하여 유거수 감소 및 열섬 현상을 감소 시키는 방안, agroforestry 실천을 통한 식량과 섬유질의 동 시 생산과 생물의 서식지를 제공하는 방안, 생물다양성과 생태계 기능을 극대화 할 수 있는 방안 등이 해당된다.

지속적 토양관리는 단기적 및 장기적 토양의 요구를 수 용하여야 하며, 다양한 생태계의 균형적인 기능 유지, 토양 의 질 및 기능의 회복력 등을 고려해야 할 것이다. 이러한 지속적 토양관리 기술과 이행에 관한 전략 개발은 다양한 분야의 학제간 연구가 필요하다.

토양환경의 연구 방향 21 세기에 있어서 토양환경의 연구는 현대 농업의 목표를 달성하기 위해 지속적인 관리기 술의 개발 및 이행이 필수적으로 요구된다. 최근 토양과 토 양학에 관한 관심이 증대되고 있는데 이는 토양에서 일어나 는 생물지구화학적 과정이 지구 기후변화, 토양질 저하, 토 양복원, 영양소 및 오염물질의 이동과 동태, 토양과 수자원의 질 향상과 보전, 식량 공급 및 안전성, 생태계의 기능, 습지의 기능 등 다양한 농업적, 환경적, 생태계적 이슈들에 영향을 미 치고 있다는 것은 인식하고 있기 때문이다 (Special Issues of Science, 2004). Science에서는 토양을 'final frontier'로 표기하고 있다. 이에 따라 토양환경의 연구는 토양에서 일 어나는 물리, 화학, 생물학적 반응과 과정들의 역동성, 안정 성, 반응 속도 및 효율성에 근거하여 진행되어야 할 것이다 (Rice, 2009).

토양학은 근본적으로 복합학문이며, 광범위한 범위에서의 시간과 공간을 포함하는 물리적, 화학적, 생물학적 반응들 에 관한 지식을 통합적으로 연구하여야 한다. 이에 따라 토 양학자는 분자수준에서 지형 (landscape) 수준에 이르기 까 지 통합적이며 융복합적인 학제간 연구를 수행해야 할 것이
다. 이 과정은 환경에서 일어나는 생물지구화학적 반응과 과 정, 토지이용과 질 저하, 기후변화, 식량 안보, 수질 등과 관 련된 이슈들을 설명할 수 있어야 한다.

이를 위해 토양학자들에게 공통적으로 제기되는 문제들 은 다음과 같다. 대기, 식생 및 수계 권역에 영향을 주는 토 양의 물리적, 화학적, 생물학적 과정을 얼마나 이해하고 있 는가? 토양계의 분자 수준에서 이온, 화합물, 미생물의 이 동과 동태를 결정할 수 있는 화학적 상호작용은 무엇인가? 토양 지하부위의 생물다양성은 무엇에 의해 조절되는가? 이 러한 생물다양성은 토양의 기능에 어떤 영향을 미칠까? 토 양의 물리화학적 생물학적 특성과 반응을 현장에서 또는 실 험실에서 측정할 수 있는 새로운 방법은 개발되어 있는가? 토양의 회복력과 안전성을 평가할 수 있는 핵심적인 지표는 무엇인가? 토양은 얼마나 다양하며 현장에서의 토양의 구 성은 토양에서 일어나는 반응과 과정에 얼마나 영향을 미칠 까? 등이다 (Rice, 2009).

위에서 제기된 질문들에 관한 답을 제공하는 것이 미래 토양환경학의 연구 방향이 될 수 있다. 기초적 토양학 연구 범위 내에서 우선순위와 도전 과제의 발굴, 학제간 연구를 위한 기회 마련, 토양연구의 진보를 위한 기술적 기회 마련 및 학생 또는 젊은 학자들을 위한 기술이전 방안 들이 필요 한 실정이다.

미래 토양학 연구의 중요한 도전과제는 토양연구에 가치 를 부여하고 토양학을 범지구적 이슈와 연관시키는 일이며 또한 토양학 연구를 시간적, 공간적 규모에서 이해하는 일 이다. 토양학 연구가 미세 규모에서 이행되었더라도 이를 포 장 수준에서 해석할 수 있는 방안이 제시되어야 할 것이다.

토양에 의해 제공되는 생태계의 기능에 가치를 부여할 수 있는 방법론의 개발이 필요하다. 생태계의 기능에 관한 연구는 토양에 의해 제공되는 핵심 서비스를 확인하고 정량 적으로 측정할 수 있어야 한다. 토양기능을 대표할 수 있는 적절한 지표를 발굴하여야 할 것이다. 생태계의 기능과 서 비스를 파악하기 위해 장기적인 모니터링이 필요하다. 아울 러 토양학을 도시생태계의 연구와 통합하여 추진할 필요가 있다.

토양의 질과 인체 건강과의 관련성을 연구해야 할 것이다. 가능하면 지형 (landscape) 수준에서 평가되어야 할 것이다. 토양관리 방안이 인간건강에 영향을 미치는 오염원이나 생 물체의 이동과 동태에 미치는 영향, 사막화가 진행되는 경 우 토양입자가 인체건강에 미치는 영향, 토양 질이 수질과 인체건강에 미치는 역할을 구명할 필요가 있다.

토양학 학문 영역 내에서 뿐 아니라 다른 학문과의 경계 를 이해하기 위해 토양에서의 이동현상을 이해하고 이를 지 구적 차원에서의 과정으로 확대하여 통합적으로 이해할 필 요가 있다. 예를 들어 토양과 대기 경계에서 물질의 이동과 정에 관한 연구를 통해 기후변화와 관련 있는 가스의 이동 
연구, 토양을 통과한 물의 이동이 수계권역에 미치는 영향, 토양에 있는 바이러스와 다른 미생물의 이동이 인체건강에 미치는 영향, 이동을 촉진할 수 있는 토양 colloids의 역할 등을 이해하여야 한다.

토양-식물체-미생물 경계면에서의 연구가 필요하다. 이 는 영양소의 흡수와 이동, 물질 순환, 오염원의 이동과 동 태, 토양모암의 풍화와 토양의 생성, 토양의 물리, 화학적, 생물학적 반응과 과정을 이해하는데 필수적이다. 이 분야에서 는 유전자 기법을 활용해야 할 것이다. 아울러 biofilm이 지 구화학적 과정과 반응에 미치는 영향을 구명해야 할 것이다.

토양에서 일어나는 물리, 화학, 생물적 반응들은 서로 상 호적으로 연결되어 일어난다. 이를 이미징 기법을 이용하여 구명하거나 동력적인 반응을 이해하여야 할 것이다. 아울러 토양의 물리, 화학, 생물적 반응간의 자동제어 (feedback) 기작에 관한 이해를 증진시켜야 한다. 또한 기후변화 등과 같은 외적 이슈에 의해 영향을 받을 경우 토양의 반응은 어 떻게 변화되는지를 구명해야 할 것이다. 인간 활동으로 부 터 토양 질이 저하되었을 경우 장기적인 측면에서 토양의 회복력을 연구해야 한다.

토양학에서 자료의 수집, 통합 분석 및 해석 방안에 관하 여 연구되어야 한다. 기존의 자료는 표준화되고 객관적으로 처리되어 다른 분야의 연구자들과 정보의 교환이 가능해야 한다. 자료는 시간적, 공간적 수준에서의 모델링을 가능하 게 해 주며 새로운 측정기법의 개발에도 유용하다.

토양학 연구에 적용할 수 있는 도구와 기법의 개발이 중 요하다. 현미경적인 기술과 분광학적 기술의 융합기술은 토
양환경연구에 매우 중요한 단서를 제공하게 된다. Isotopic tracer의 활용, 토양의 화학, 구조 및 생물학을 현장에서 연 구할 수 있는 새로운 기법의 개발, 모델링 기법의 개발, 수 리적 계산적 용량의 증대 등을 들 수 있다.

이러한 토양환경의 연구는 학제간 공동연구와 첨단 연구 분야와의 융합을 필요로 한다. 토양은 근본적으로 복합학문 이므로 물리학, 화학, 생물학, 지질학, 수문학, 미생물학, 식물학 등의 학문과 통합적으로 관련되어 있다. 이런 이유 로 인해 토양학자는 복잡한 환경시스템을 구명하기 위해 첨 단과학기술과 방법을 도입하는데 선구적 역할을 해 오고 있 다. 다양한 학문 분야와의 경계면에서의 연구는 획기적인 연구결과를 가져올 수 있다. 따라서 토양환경 연구는 학제 간 연구를 필수적으로 고려해야 한다.

DeJong et al. (2011)은 “토양생물계공학 (Soil engineering in vivo')'이라는 개념을 통하여 토양에서 일어나는 토양탄 소격리, 수변구역의 구축, 인프라 구조의 재생, brownfield의 정화, 유해폐기물의 처리, 수자원의 보호, 기구온난화 등의 현상을 설명하고 있다. 이는 보다 진보적이고 통합적인 학제 간 연구의 중요성을 강조하고 있다. 이는 토양을 살아있는 시스템으로 간주하고, 토양의 자연적인 용량은 동시 다발적 으로 일어나는 많은 반응들을 수용할 수 있다고 간주하고 있다. 이는 21 세기가 직면하고 있는 다양한 환경적, 경제적 이슈들을 토양이 복합적이며 지속적으로 해결할 수 있는 가 능성을 설명하는 새로운 개념이다. Fig. 3 은 토양환경연구 에서 융복합-학제간 연구의 대표적인 예로서 토양생물계공 학의 접근에 관한 개념도를 보여주고 있다.

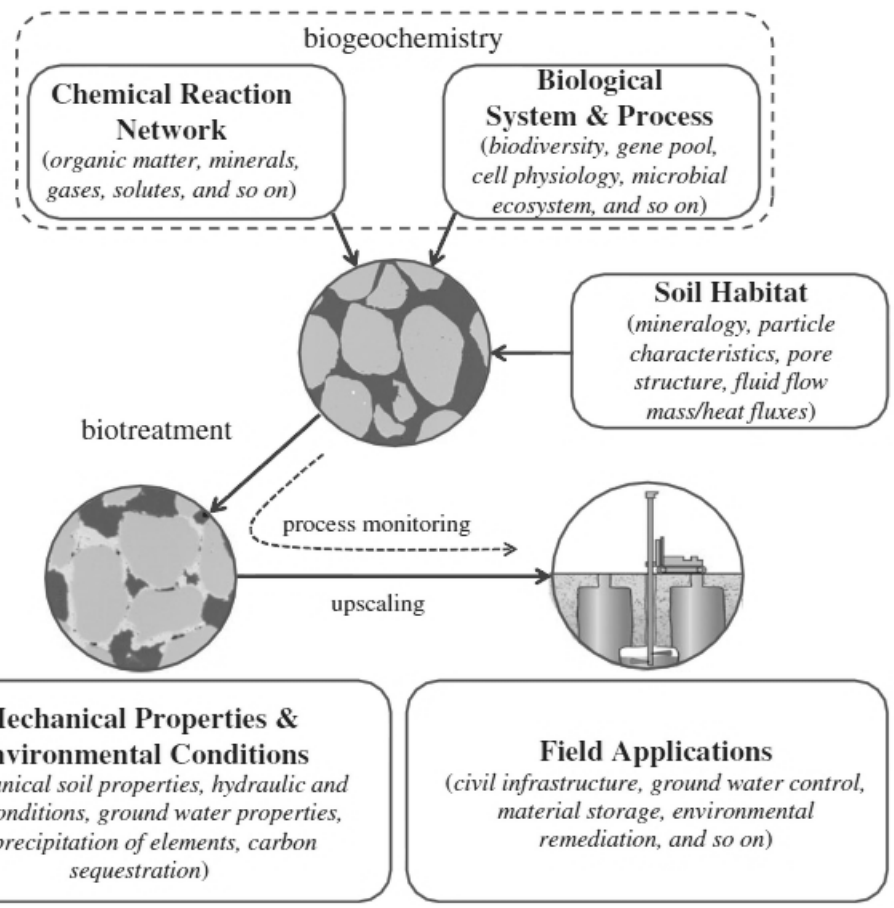

Fig. 3. Conceptural framework of the soil engineering in vivo (adapted from DeJong et al., 2011). 
토양학 에서 획기적으로 연구된 결과들은 이해당사자, 정 책입안자 및 소비자에게 효율적으로 전달할 수 있는 필요성 이 크다. 따라서 토양학자들은 사회학, 인류학, 경제학 등 분 야의 전문가와 공동연구를 통해 토양환경연구 결과를 획기적 이고 발전된 정책발굴의 수단으로 활용할 수 있어야 할 것이 다. 지속적 농업을 달성하는 것은 과학, 정책 및 시장에서의 획기적인 변화를 요구하고 있다 (Reganold et al., 2011). 이러한 토양환경 연구를 위해 전문인력을 양성할 필요가 있다. 따라서 토양학 강의 교재와 실험서도 연구 방향에서 와 같이 복합적이며 학제간 지식을 교육할 수 있는 방향으 로 전환되어야 할 것이다. 아울러 교육과정을 통해 토양학 은 전공하는 학생들이 다른 학문분야를 다양하게 경험할 수 있는 기회를 제공해야 할 것이다. 새로 개발되는 기술과 방 법을 경험할 수 있는 실험과 수련의 기회를 제공해야 할 것 이다. 토양학을 전공하는 학생들이 사회적으로 요구되는 이 슈에 적절하게 대응하고 비전문가와 대화를 할 수 있는 능 력을 배양해야 할 것이다.

\section{사 사}

본 연구는 농촌진흥청에서 지원한 '농식품분야 국내외 기 술 동향 및 전망 (9-25-61)' 과제의 일환으로 수행되었으며 이에 감사드립니다.

\section{인 용 문 헌}

Cakmak, I. 2002. Plant nutrition research: Priorities to meet human needs for food in sustainable ways. Plant and Soil 247:3-24.

Clay, J. 2004. World agriculture and the environment: a commodity by commodity guide to impacts and practices. Island Press, Washington DC, USA, p. 570.

Cohen, J.E. 2003. The human population: next half century. Science 320:1172-1175.

DeJong, J.T., K. Soga, S.A. Banwart, W.R. Whalley, T.R. Ginn, D.C. Nelson, B.M. Mortensen, B.C. Martinez, and T. Barkouki. 2011. Soil engineering in vivo: harnessing natural biogeochemical systems for sustainable, multi-functional engineering solutions. J. Royal Soc. Interface 8:1-15.

FAO (FOOD AND AGRICULTURE ORGANIZATION OF THE UNITED NATIONS). 2011. Save and Grow. pp.112.
Foley, J.A., R. DeFries, G.P. Asner, C. Barford, G. Bonan, S.R. Carpenter, F. S. Chapin, M.T. Coe, G.C. Daily, H.K. Gibbs, J.H. Helkowski, T. Holloway, E.A. Howard, C.J. Kucharik, C. Monfreda, J.A. Patz, I.C. Prentice, N. Ramankutty, and P.K. Snyder. 2005. Global consequences of land use. Science 309:570-574.

Greenwood, D.J. 1989. The 1988 Shell Lecture: Plant nutrition and human welfare: The World Scene. J. Sci. food Agric. 48:387-410.

Grusak, M.A. and D. DellaPenna. 1999. Improving the nutrient composition of plants to enhance human nutrition and health. Annu. Rev. Plant Physiol. Plant Mol. Biol. 50:133-161.

Lal, R. 2005. World crop residues production and implications of this use as a biofuel. Environ. Int. 31:575-584.

Lal, R. 2006. Enhancing crop yields in developing countries through restoration of soil organic carbon pool in agricultural lands. Land Degrad. Dev. 17:197-206.

Lal, R. 2008. Soils and Sustainable Agriculture: A Review. Agron. Sustain. Dev. 28:57-64.

Lal, R. 2009. Ten tenets of sustainable soil management. J. Soil Water Conservation. 64:20A-21A.

Moldan, D. (Ed). 2007. Water for food, water for life. Earthscan, USA, p. 645 .

Reganold, J.P., D. Jackson-Smith, S. S. Batie, R.R. Harwood, J.L. Kornegay, D. Bucks, C.B. Flora, J.C. Hanson, W.A. Jury, D. Meyer, A. Schumacher Jr., H. Sehmsdorf, C. Shennan, L. A. Thrupp, and P. Willis. 2011. Transforming U.S. Agriculture. Science 332:670-671.

Rice, C.W. 2009. (Chair). Frontiers in soil science research: Report of a workshop. National Research Council of the National Academies. The National Academy Press, Washington DC, USA. P. 80.

Tilman, D., J. Hill and C. Lehman. 2006. Carbon-negative biofuels from low-input high-diversity grassland biomass. Science 314:1598-1660.

United Nations Population Fund (UNFPA). 2011. http://www. unfpa.org/public/

Yang, J.E. 2008. Plant Welfare. http://www.ekn.kr Oct. 22, 2008.

Yang, J.E., J.B. Chung, J.E. Kim, and K.S. Lee. 2008. Agricultural Environment. CIR Pub. Co., Korea (Korean).

Yang, J.E. 2011. Soil Science - Meeting Societal Needs and Challenges: The International Perspective. Soil Sci. Soc. Am. Annual Meeting. http://a-c-s.confex.com/crops/2011am/ webprogram/Paper67048.html 